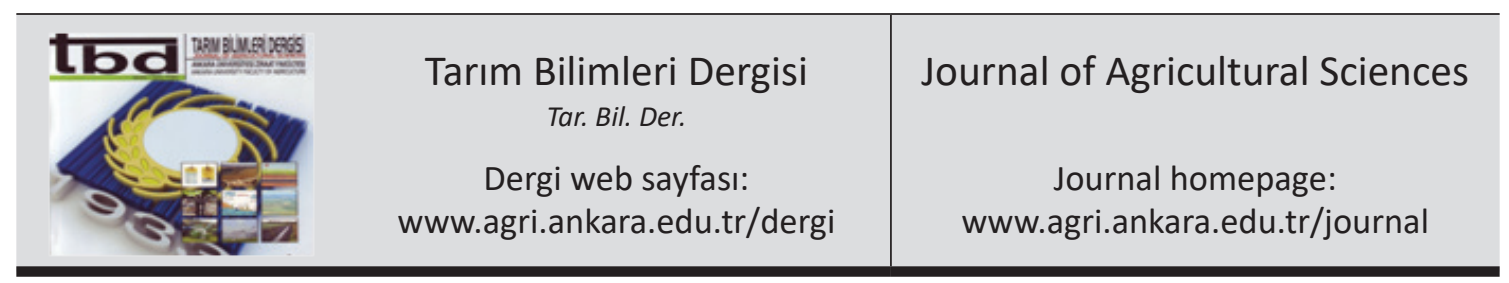

\title{
Identification of Sunflower (Helianthus annuus L.) Genotypes Tolerant to Water Stress
}

\author{
Ali Beyhan UÇAK ${ }^{\mathrm{a}}$ \\ ${ }^{a}$ Siirt University, Faculty of Agriculture, Department of Biosystem Engineering, Siirt, TURKEY
}

\section{ARTICLE INFO}

Research Article

DOI: 10.15832 /ankutbd.456645

Corresponding Author: Ali Beyhan UÇAK, E-mail: abucak@siirt.edu.tr, Tel: +90 (484) 2542057

Received: 22 March 2017, Received in Revised Form: 31 July 2017, Accepted: 20 September 2017

\begin{abstract}
The present research was carried out to determine water-stress tolerance of linoleic sunflower genotypes (P64LE119, PR63F73, P64LL62) grown under different water stress conditions [no water-stress $\left(\mathrm{I}_{100}\right)$; mild water-stress $\left(\mathrm{I}_{70}\right)$; strong water-stress $\left.\left(\mathrm{I}_{35}\right)\right]$ in the years 2015 and 2016. Variance analyses revealed significant differences between the genotypes $(\mathrm{P}<0.01)$. As the average of two years, the greatest yield was obtained from no water-stress $\mathrm{x}$ genotype interaction $\left(\mathrm{I}_{100} \times\right.$ P64LE119) with $4094.66 \mathrm{~kg} \mathrm{ha}^{-1}$, the lowest yield was obtained from strong water stress $\mathrm{x}$ genotype interaction $\left(\mathrm{I}_{35} \mathrm{xPR} 63 \mathrm{~F} 73\right.$ ) with $2487.81 \mathrm{~kg} \mathrm{ha}^{-1}$. Again as the average of two years, the greatest chlorophyll content was obtained from no water-stress $\mathrm{x}$ genotype interaction ( $\mathrm{I}_{100} \mathrm{xP}$ 64LE119) with $49.83 \mathrm{spad}$, the lowest value was obtained from strong water stress $x$ genotype interaction $\left(\mathrm{I}_{35} \mathrm{xPR} 63 \mathrm{~F} 73\right)$ with 34.39 spad. The greatest crop water stress index was obtained from strong water stress $x$ genotype interaction $\left(\mathrm{I}_{35} \mathrm{xPR} 63 \mathrm{~F} 73\right)$ with 0.53 , the lowest value was obtained from no water-stress $x$ genotype interaction $\left(\mathrm{I}_{100} \mathrm{xP}\right.$ 64LE119) with 0.21 . The P64LE119 genotype with optimum water use efficiency and prominent with crop water stress index and chlorophyll content both in no water-stress and strong water stress treatments was identified as water stress-resistant and the genotype was considered to have reliable characteristics potentially to be used in further water stress-resistance studies.
\end{abstract}

Keywords: Sunflower; Water stress; Crop water stress index; Tolerance; Chlorophyll

(C) Ankara Üniversitesi Ziraat Fakültesi

\section{Introduction}

Today, agronomists and plant breeders are focused on yields rather than survival of the plants. Breeding programs are mostly implemented to develop highyield cultivars. However, recent global warminginduced abiotic stressors have negatively influenced agricultural production activities and such impacts compelled the researchers to take new measures against the negative impacts of climate change and resultant global warming. Among the abiotic stressors, water stress, insufficient nutrition, salinity and high temperature are the leading ones (Kozlowski \& Pallardy 1997). Recession in plant growth due to deficit moisture within the plant efficient root zone (through the soil profile of 0-90 $\mathrm{cm}$ ) is defined as water stress. The initial symptoms of water stress realize at stomatal level and stomas close to prevent further moisture loss through transpiration (Flexas \& Medrano 2002). Stomal closure reduces $\mathrm{CO}_{2}$ availability in chloroplasts and negatively influences net photosynthesis rates 
(Cornic 2000). Water stress is exerted on plant tissues under drought stress and this reduces photosynthesis rates significantly (Chaves 1991). Neither the soil moisture content nor the atmospheric system can accurately put forth plant inherent water status as much as crop water stress index (Reginato \& Howe 1985; Gencoglan \& Yazar 1999). Reginato (1983) indicated that daily crop water stress index values varied based on atmospheric demands and soil moisture contents. Water stress is experienced when the plant cover temperature was equal or greater than the air temperature (Walker \& Hatfield 1979). Canopy-air temperature difference (Tc-Ta) is a significant indicator of water stress (Jackson \& Reginato 1981). Choudhury \& Idso (1984) carried out a water stress study on sunflower and reported significant effects of air and dew temperatures on plant cover temperature under high soil moisture conditions. Plant resistance to droughts and water stress are the primary target of plant breeders. For sunflowers, leaf canopy temperatures are the most significant parameters in measuring plant tolerance to water stress under stress conditions (Skoric 2009). Moroni et al (2012) indicated the canopy (leaf-canopy) temperature as the fastest and the most accurate means of measuring water stress and pointed out that this parameter could be used as a selection criterion in breeding studies. Crop water stress index values vary based on plant genotypes, cultivars, environmental and climate conditions (Testi et al 2008). Water stress is among the most important factors restricting plant production activities and may result in significant changes in chlorophyll content and components through hindering photosynthetic activity in plants (Mozaffari et al 1996). The parameters to be used in identification of drought or water stress should be easy, rapid, cheap and repeatable (Kaleem et al 2009; Moroni et al 2012). Oraki et al (2012) reported increased chlorophyll b levels, decreased chlorophyll a and yield levels with increasing water stress levels. Despite the studies about drought (water stress) tolerance of wheat and chickpea plants (Gunes et al 2008), the studies about plant responds to water stress in sunflower are quite limited. For sunflower, efficient selection criteria to be used in distinguishing potential status of the plants against water stress haven't been fully elucidated, yet. That is why in present study (2015-2016), 3 different irrigation treatments $\left(\mathrm{I}_{100}\right.$, $\mathrm{I}_{70}, \mathrm{I}_{35}$ ) were employed. The present study was conducted under field conditions in 2015 and 2016 to determine water stress resistance of 3 sunflower genotypes (P64LE119, PR63F73, P64LL62) grown under strong water-stress, mild water-stress and no water-stress conditions by using kernel yield, crop water stress index and chlorophyll content values.

\section{Material and Methods}

A pre-study was carried out under Siirt conditions in 2014 with two sunflower genotypes (PR63F73, P64LL62) and 4 irrigation treatments $\left(\mathrm{I}_{100}, \mathrm{I}_{70}, \mathrm{I}_{35}, \mathrm{I}_{0}\right)$. Correlation analyses revealed that yield positively correlated with chlorophyll content (CC) (86\%), water use efficiency (WUE) (74\%) and soil moisture content $(61 \%)(\mathrm{P}<0.01)$ and negatively correlated with crop water stress index (CWSI) (79\%). A negative correlation was also observed between CWSI and soil moisture content $(84 \%)(\mathrm{P}<0.01)$. In that pre-study, irrigation treatments were selected as $\mathrm{I}_{100}, \mathrm{I}_{70}, \mathrm{I}_{35}$ and $\mathrm{I}_{0}$. However, $\mathrm{I}_{0}$ treatment was not found to be assessable with regard to wateryield relations, thus removed from the study and $\left(\mathrm{I}_{35}\right)$ treatment was included instead to represent strong water stress conditions. Experiments were conducted under natural field conditions since it is quite hard to transfer the results of the studies carried out under controlled conditions like greenhouses or growth chambers into the practice. Sowing was performed late on $30^{\text {th }}$ of May to shift the negative impacts of precipitations in May. Experiments were carried out over the experimental fields of Siirt Province during the sunflower growing seasons of 2015 and 2016. The research site has an altitude of $894 \mathrm{~m}$ and is located on $37^{\circ} 58^{\prime} \mathrm{N}$ and $41^{\circ} 50^{\prime} \mathrm{E}$. Linoleic P64LE119, PR63F73, P64LL62 sunflower genotypes were used as the plant material of the study. Long-term and annual climate data of the research site (during sunflower growing seasons) are provided in Table 1. 
Table 1- Climate data for the years of 2015 and 2016 and long-term averages (1962-2014)

\begin{tabular}{|c|c|c|c|c|c|c|c|c|}
\hline Years & Months & $\begin{array}{c}\text { Mean } \\
\text { maximum } \\
\text { temperature } \\
\left({ }^{\circ} \mathrm{C}\right)\end{array}$ & $\begin{array}{c}\text { Mean } \\
\text { temperature } \\
\left({ }^{\circ} \mathrm{C}\right)\end{array}$ & $\begin{array}{c}\text { Mean } \\
\text { minimum } \\
\text { temperature } \\
\left({ }^{\circ} \mathrm{C}\right)\end{array}$ & $\begin{array}{c}\text { Mean } \\
\text { humidity } \\
(\%)\end{array}$ & $\begin{array}{c}\text { Mean wind } \\
\text { speed } \\
\left(m s^{-1}\right)\end{array}$ & $\begin{array}{c}\text { Mean daily } \\
\text { sunshine } \\
\text { (h) }\end{array}$ & $\begin{array}{c}\text { Total } \\
\text { precipitation } \\
(\mathrm{mm})\end{array}$ \\
\hline \multirow{6}{*}{$\begin{array}{l}\text { Average } \\
1962- \\
2014\end{array}$} & May & 25.20 & 19.40 & 9.00 & 49.30 & 1.00 & 9.10 & 36.90 \\
\hline & June & 27.20 & 26.00 & 17.80 & 34.90 & 1.10 & 11.60 & 11.50 \\
\hline & July & 35.10 & 30.50 & 23.40 & 30.30 & 1.10 & 12.30 & 0.60 \\
\hline & August & 34.50 & 30.30 & 27.00 & 29.50 & 1.00 & 11.40 & 2.70 \\
\hline & September & 30.00 & 25.10 & 14.70 & 37.40 & 1.00 & 10.10 & 7.00 \\
\hline & October & 24.50 & 17.90 & 12.70 & 42.00 & 1.00 & 7.20 & 50.90 \\
\hline \multirow{6}{*}{2015} & May & 26.62 & 19.29 & 14.52 & 50.87 & 1.00 & 8.70 & 39.60 \\
\hline & June & 26.09 & 28.16 & 20.00 & 35.50 & 1.10 & 11.50 & 10.60 \\
\hline & July & 34.13 & 31.45 & 24.35 & 32.69 & 1.00 & 12.40 & 0.10 \\
\hline & August & 33.92 & 31.19 & 24.23 & 32.95 & 1.00 & 11.30 & 0.40 \\
\hline & September & 31.23 & 25.43 & 21.50 & 39.90 & 1.10 & 10.00 & 9.20 \\
\hline & October & 24.30 & 16.80 & 11.50 & 42.30 & 1.10 & 7.00 & 55.10 \\
\hline \multirow{6}{*}{2016} & May & 24.69 & 21.29 & 14.59 & 51.77 & 1.00 & 9.30 & 37.70 \\
\hline & June & 28.19 & 28.41 & 20.25 & 34.40 & 1.10 & 12.00 & 9.30 \\
\hline & July & 36.24 & 33.19 & 25.35 & 29.69 & 1.00 & 12.50 & 0.10 \\
\hline & August & 35.92 & 32.45 & 24.73 & 29.95 & 1.00 & 11.50 & 0.00 \\
\hline & September & 32.23 & 27.43 & 21.65 & 36.79 & 1.10 & 10.00 & 12.20 \\
\hline & October & 21.10 & 19.70 & 12.00 & 44.20 & 1.00 & 7.30 & 69.20 \\
\hline
\end{tabular}

Soil samples were taken before sowing from 0-90 cm soil profile (from three depth segments as 0-30, 30-60 and 60-90 cm). Soil moisture content at field capacity $(33 \mathrm{kPa})$ was determined in accordance with Klute (1986) and bulk density with Blake \& Hartge (1986). Disturbed samples were subjected to organic matter, texture and permanent wilting point analyses. Water holding capacity at permanent wilting point $(1500 \mathrm{kPa})$ was determined in accordance with Klute (1986). Soil physicochemical characteristics are provided in Table 2.

Experimental soils were classified as brown forest soil with low electrical conductivity and salinity, low phosphorus content, high potassium content and medium level organic matter content and lime levels were not posing any problems for plant growth.

Irrigation water quality parameters were determined in accordance with the method specified by Tuzuner (1990). Irrigation water quality class
Table 2- Some physical and chemical soil characteristics of the research site

\begin{tabular}{lrrr}
\hline \multirow{2}{*}{ Properties } & \multicolumn{3}{c}{ Soil layer $(\mathrm{cm})$} \\
\cline { 2 - 4 } & $0-30$ & $30-60$ & $60-90$ \\
\hline Clay (\%) & 62.00 & 58.00 & 55.00 \\
Silt (\%) & 20.00 & 25.00 & 32.00 \\
Sand (\%) & 18.00 & 17.00 & 13.00 \\
Texture & Clay & Clay & Clay \\
Field capacity $\left(\mathrm{Pw}_{\mathrm{fc}}\right)$ & 33.52 & 36.04 & 35.38 \\
Permanent wilting point (Pwp) & 24.44 & 26.08 & 25.57 \\
Bulk density $\left(\mathrm{g} \mathrm{cm}^{-3}\right)$ & 1.42 & 1.39 & 1.41 \\
pH $\left(1.25 \mathrm{sw}^{-1}\right)$ & 7.50 & 7.66 & 7.91 \\
Electrical conductivity $\left(\mathrm{dS} \mathrm{m} \mathrm{m}^{-1}\right)$ & 1.55 & 1.77 & 1.75 \\
Organic matter $(\%)_{\text {CaCO }_{3}(\%)}^{3.09}$ & 2.06 & 1.80 \\
\hline
\end{tabular}

was $\mathrm{C}_{2} \mathrm{~S}_{1}$ with an average $\mathrm{EC}$ value of $0.34 \mathrm{dS} \mathrm{m} \mathrm{m}^{-1}$ and a $\mathrm{pH}$ value of 7.21. Experiments were conducted in randomized blocks-split plots experimental design with 3 replications with genotypes (P64 
LE119, PR63 F73 and P64 LL62) on main plots and irrigation treatments $\left(\mathrm{I}_{100}, \mathrm{I}_{70}\right.$ and $\left.\mathrm{I}_{35}\right)$ on sub-plots.

Irrigation program was scheduled as to have irrigations once a week. Treatments were selected as no water-stress treatment $\left(\mathrm{I}_{100}\right)$ in which $100 \%$ of depleted moisture was supplied, mild water-stress treatment $\left(\mathrm{I}_{70}\right)$ in which $70 \%$ of depleted moisture was supplied and strong water-stress treatment $\left(\mathrm{I}_{35}\right)$ in which $35 \%$ of depleted water was supplied. Therefore, one full irrigation and two deficit irrigation treatments were created.

Drip irrigation was used to perform irrigations. A lateral line $(20 \mathrm{~mm}$ and $4 \mathrm{~atm}$ operational pressure, $0.33 \mathrm{~m}_{\text {apart }} 4 \mathrm{~L} \mathrm{~h}^{-1}$ drippers) was placed along each plant row. Soil infiltration rate was measured as 7 $\mathrm{mm} \mathrm{h}^{-1}$. Deep percolation and surface runoff were not considered. Each plot has a size of $6 \times 2.8 \mathrm{~m}$ (16.8 $\mathrm{m}^{2}$ ) with 4 plant rows with $70 \mathrm{~cm}$ row spacing and $30 \mathrm{~cm}$ on-row plant spacing. A buffer zone of $2 \mathrm{~m}$ was placed between the experimental plots as to prevent interactions.

All of the phosphorus fertilizer (pure $90 \mathrm{~kg} \mathrm{ha}^{-1}$ $\left.\mathrm{P}_{2} \mathrm{O}_{5}\right)$ and one third of nitrogen $\left(280 \mathrm{~kg} \mathrm{ha}^{-1} \mathrm{~N}\right)$ were supplied at sowing. Rest of the nitrogen was given when the plants were $40-50 \mathrm{~cm}$ tall.

Gravimetric moisture content of each layer (030, 30-60 and 60-90) was converted into depth with Equation 1.

$d=\frac{\left(P w_{F C}-P w_{A W}\right) \times A s \times D}{100}$

Where; $d$, soil moisture content in depth $(\mathrm{mm})$; $P w_{F C}$ is field capacity (\%); $P w_{A W}$ is moisture content of each layer (\%); As is bulk density $\left(\mathrm{g} \mathrm{cm}^{-3}\right) ; D$ is layer depth $(\mathrm{mm})$. Volume of water to be applied was calculated by using the following Equation 2.

$d_{T(0-90)}=d_{(0-30)}+d_{(30-60)}+d_{(60-90)}$

Where; $d_{T(0-90)}$ is soil moisture at $0-90 \mathrm{~cm}$ soil profile $(\mathrm{mm}) ; d_{(0-30)}$ is soil moisture at $0-30 \mathrm{~cm}$ soil profile $(\mathrm{mm}) ; d_{(30-60)}$ is soil moisture at $30-60 \mathrm{~cm}$ soil profile $(\mathrm{mm}) ; d_{(60-90)}$ is soil moisture at $60-90 \mathrm{~cm}$ soil profile $(\mathrm{mm})$.
Volume of water to be applied to each plot was calculated by Equation 3 .

$V=d_{T} \times A \times U_{0} \times P$

Where; $V$ is volume of water to be applied (L); $A$ is plot size $\left(\mathrm{m}^{2}\right) ; U_{0}$ is deficit ratio (\%) and $P$ is cover ratio $(\%)$.

Plant canopy width was divided by row spacing to get cover ratios (CR). The ratio was taken as 0.30 and 0.80 for cover ratios of $30 \%$ and $80 \%$. The principles specified in Gungor et al (2006) were employed to find out the amount of water to be used in each plot.

Water budget method was used to calculate monthly and seasonal evapotranspiration values (Sahin et al 2007). Water use efficiency (WUE) values were calculated by using Equation 4 (Scott 2000).

$W U E=\frac{Y}{E T_{a}}$

Where; WUE is water use efficiency $\left(\mathrm{kg}\right.$ da $\left.\mathrm{mm}^{-1}\right)$; $Y$ is yield; $E T_{a}$ is evapotranspiration ( $\mathrm{mm}$ ).

Plant water consumptions were calculated by using Equation 5 (Sahin et al 2007).

$E T_{a}=P+I-R_{f}-D_{p} \pm \Delta S$

Where; $E T_{a}$ is evapotranspiration $(\mathrm{mm}) ; P$ is precipitation $(\mathrm{mm}) ; I$ is amount of irrigation water $(\mathrm{mm}) ; R_{f}$ is surface flow $(\mathrm{mm}) ; D_{p}$ is deep percolation $(\mathrm{mm}) ; \Delta S$ is the change in soil moisture (mm).

Change in CWSI and CC values of P64LE119, PR63F73, P64LL62 sunflower genotypes grown under $I_{100}, I_{70}$ and $I_{35}$ irrigation treatments were determined in one week intervals. CWSI and CC measurements were performed along the diagonals of each plot in four corners in three replications from the leaves close to head.

CWSI values were calculated by using Equation 6 as recommended by Idso (1982). 
$C W S I=\frac{\left[\left(T_{c}-T_{a}\right)-L L\right]}{U L-L L}$

Where; CWSI is crop water stress index; $T_{c}$ is canopy temperature $\left({ }^{\circ} \mathrm{C}\right) ; T_{a}$ is air temperature $\left({ }^{\circ} \mathrm{C}\right)$; $L L$ is lower limit of water stress; $U L$ is upper limit of water stress.

The lower limit (LL) at which plants did not experience any water stresses was calculated by the equation provided by Idso (1982) and using regression analyses between canopy-air temperature and vapor pressure deficit (VPD, $\mathrm{kPa}$ ) (Equation 7);

$$
T_{c}-T_{a}=(a-b) \times V P D
$$

Where; $a$ is intermediate section value $\left({ }^{\circ} \mathrm{C}\right) ; b$ is slope of the line $\left(\mathrm{kPa}^{\circ} \mathrm{C}^{-1}\right) ; V P D$ is vapor pressure deficit (kPa).

Vapor pressure deficit was calculated with basic psychrometric equations (Alderfasi \& Nielsen 2001). These equations are provided below;

$e_{w}=0.61078 \exp \left[\frac{17.27 T_{w}}{237.3+T_{w}}\right]$

$e_{a}=e_{w}-\left[A P \times\left(T_{a}-T_{w}\right)\right]$

Where; $e_{w}$ is saturated vapor pressure at wetbulb temperature $(\mathrm{kPa}) ; e_{a}$ is actual vapor pressure at air temperature $(\mathrm{kPa}) ; T_{w}$ is wet-bulb temperature $\left({ }^{\circ} \mathrm{C}\right) ; A$ is psychrometric constant $\left(\mathrm{kPa}^{\circ} \mathrm{C}^{-1}\right) ; P$ is barometric pressure $(\mathrm{kPa})$.

Psychrometric constant (A) was calculated from the following equation;

$A=\left[0.00066\left(1+00115 T_{w}\right)\right]$

Saturated vapor pressure was calculated by using the following equation;

$e_{a} \times T_{a}=0.61078 \exp \left[\frac{17.27 T_{a}}{237.3+T_{a}}\right]$

Vapor pressure deficit (VPD) was calculated as the difference of saturated vapor pressure at drybulb temperature from the actual vapor pressure at the same temperature;
$V P D=\left[\left(e_{a} \times T_{a}\right)-e_{a}\right]$

Where; $e_{a} \times T_{a}$ is saturated vapor pressure at drybulb temperature $(\mathrm{kPa})$.

The upper limit (UL) at which plants experienced full-water stress was calculated by using the equations recommended by Idso et al (1981);

$T_{c}-T_{a}=(a-b) \times V P G$

$V P G=\left[\left(e_{a} \times T_{a}\right)-e_{a} \times\left(T_{a}+a\right)\right]$

Where; $a$ and $b$ are lower limits (LL) at which there are no water stress; $V P G$ is slope of negative atmospheric vapor pressure required for the training of zero canopy-air vapor pressure.

$\mathrm{CC}$ of the genotypes was measured with a portable chlorophyll meter. Measurements were initiated when the plant cover ratio of the plots reached to $80 \%$ and performed throughout the growing season before and after the irrigations from the same plant and same leaves. Measurements were performed in days with clear sky and between 12:00 14:00 hours when the change in sun-ray angles the least. Chlorophyll-meter measurements were taken from the leaves just beneath the sunflower head, the device was oriented over the leaf as not to create a shade over it and 3 subsequent measurements (a total of 12 readings) were taken along the diagonal of the plot. CC increases as the value approaches to 1 and decreases as the value approaches to 0 .

Harvest was performed when the seed moisture content decreased to $10 \%$ to determine the yields. Side rows and $0.5 \mathrm{~m}$ space at top and bottom of inner two rows were omitted as to consider side effects.

Analysis of variance (ANOVA) was performed in accordance with randomized blocks-split plots experimental design. Significant treatments were then subjected to LSD (Least Significant Difference) multiple comparison tests. Correlation analyses were carried out to identify the relationships between the traits. The directions of the relationships (positive or negative) were determined. Analyses were carried out with JUMP 5.0.1a statistical software (Der \& Everitt 2002). 


\section{Results and Discussion}

Seven irrigations were performed in all irrigation treatments. Irrigation water applied in 2015 and 2016 was measured as 550.80 and $624.46 \mathrm{~mm}$ in no water-stress treatments and as 216.20 and 245.09 $\mathrm{mm}$ in strong water-stress treatments. Seasonal plant water consumptions varied between 626.30-696.66 $\mathrm{mm}$ in no water-stress treatments and between 291.70-317.29 $\mathrm{mm}$ in strong water-stress treatments (Table 3). Higher ET values of strong waterstress treatments were because plants continued to benefit from the residual moisture in soil from the winter precipitations even after termination of irrigations. Water consumptions of the same plant genotypes may vary based on climate and regions and such values may even vary within the same region. Relevant differences might be due to the differences in plant genotypes, climate parameters, soil properties, method of irrigation and irrigation schedules.

The variations in yield and physiological characteristics of sunflower genotypes with irrigation water quantities are provided in Table 3, correlation coefficients between yield and other parameters are provided in Table 4. Significant differences were observed in yield, CWSI, CC and WUE values of the genotypes $(\mathrm{P}<0.01)$ and such differences were then subjected to LSD test (grouping) (Table 3). In the first year of experiments, the greatest yield in strong water-stress treatments $\left(2657.67 \mathrm{~kg} \mathrm{ha}^{-1}\right)$ was obtained from $\mathrm{I}_{35} \mathrm{xP} 64 \mathrm{LE} 119$ interaction with a low CWSI (0.31) and CC (37.13 spad) value and the lowest yield (2597.63 $\left.\mathrm{kg} \mathrm{ha}^{-1}\right)$ was obtained from $\mathrm{I}_{35} \mathrm{xPR63F73}$ interaction with a high CWSI (0.49) and a low CC (34.73 spad) value. The greatest yield in no water-stress treatments $\left(4214.66 \mathrm{~kg} \mathrm{ha}^{-1}\right)$ of the first year was obtained from $\mathrm{I}_{100} \times \mathrm{P} 64 \mathrm{LE} 119$ interaction with a low CWSI (0.19) and a high CC $(50.33 \mathrm{spad})$ values and the lowest yield (3914.65 $\mathrm{kg} \mathrm{ha}^{-1}$ ) was obtained from $\mathrm{I}_{100}$ xPR63F73 interaction with a high CWSI (0.26) and a low CC (46.25 spad) value. Genotypes also had significant impacts on yields $(\mathrm{P}<0.01)$. The greatest yield $\left(3519.0 \mathrm{~kg} \mathrm{ha}^{-1}\right)$ was obtained from P64LE119 genotype and the lowest yield (3398.0 $\left.\mathrm{kg} \mathrm{ha}^{-1}\right)$ was obtained from PR63F73 genotype. In the second year of experiments, the greatest yield $\left(2685.66 \mathrm{~kg} \mathrm{ha}^{-1}\right)$ in strong water-stress treatments was obtained from $\mathrm{I}_{35} \mathrm{xP64LE119}$ interaction with a low CWSI (0.37) and a high CC (36.11 spad) value and the lowest yield $\left(2378.00 \mathrm{~kg} \mathrm{ha}^{-1}\right)$ was obtained from $\mathrm{I}_{35} \mathrm{xPR} 63 \mathrm{~F} 73$ interaction with a high CWSI (0.56) and a low CC (34.04) value. The greatest yield (3974.66 $\left.\mathrm{kg} \mathrm{ha}^{-1}\right)$ in no water-stress treatments of the second year was obtained from $\mathrm{I}_{100} \times \mathrm{P} 64 \mathrm{LE} 119$ interaction with a low CWSI (0.22) and a high CC (49.32 spad) value and the lowest yield $\left(3800.0 \mathrm{~kg} \mathrm{ha}^{-1}\right)$ was obtained from $\mathrm{I}_{100} \mathrm{xPR63F73}$ interaction with a high CWSI (0.28) and a low CC (45.76) value. Variance analyses revealed that genotypes had significant effects on yields also in the second year of the experiments $(\mathrm{P}<0.01)$. Similar to the first year, the greatest yield (3393.33 $\mathrm{kg} \mathrm{ha}^{-1}$ ) was observed in P64LE119 genotype and the least (3225.88 $\left.\mathrm{kg} \mathrm{ha}^{-1}\right)$ in PR63F73 genotype. The other genotype (P64LL62) was placed in between these two genotypes in both years. As to conclude, significant interactions were observed between irrigation treatments and genotypes. Complying with the present findings, Kassab et al (2012) also reported significant interactions between irrigation treatments and genotypes. Water deficits in flowering period may cause considerable yield losses (Ali \& Shui 2009). In addition, Afkari (2010), Kassab et al (2012) showed that water deficits significantly reduced plant heights, number of seeds per head, leaf area index and leaf relative water content of sunflower. Current findings comply with the results of Ali \& Shui (2009), Afkari (2010) and Kassab et al (2012). However, Alahdadi et al (2011) reported substantial yield losses at short-term water deficits. Moisture deficiencies may negatively influence plant regeneration since sunflower is quite sensitive to drought stress during pollination period (Hajhassani-Asl et al 2009). Zaeifizade \& Goliov (2009) showed that deficit moisture levels from budding to the end of flowering had devastating impacts on yields. In addition, Chimenti et al (2002) indicated flowering and seed maturity stages as the sensitive stages of sunflower to water-stress. Current results are in line with the findings of Hajhassani-Asl et al (2009), Zaeifizade \& Goliov 
(2009) and Chimenti et al (2002). Darvishzadeh et al (2010) carried out a selection study for water stress resistance of sunflower genotypes and reported that relevant genotypes exhibited similar performances both under water stress conditions and optimum conditions. Therefore in present study, the genotype P64LE119 with similar yield performance under both strong water-stress and no water-stress conditions were found to be prominent. Then, it was determined that this genotype could be used in studies to be carried out for the resistance or tolerance of sunflower genotypes to water stress and other abiotic stress factors.

In the first year of experiments, the greatest CC (37.13 spad) in strong water-stress treatments was obtained from $\mathrm{I}_{35} \mathrm{x}$ 64LE119 interaction and the lowest value $(34.73 \mathrm{spad})$ was obtained from $\mathrm{I}_{35} \mathrm{xPR} 63 \mathrm{~F} 73$ interaction. The greatest CC $(50.33$ spad) in no water-stress treatments of the first year was obtained from $\mathrm{I}_{100} \times$ P64LE119 interaction and the lowest value (46.25 spad) was obtained from $\mathrm{I}_{100} \mathrm{xPR} 63 \mathrm{~F} 73$ interaction. Variance analyses revealed that genotypes had also significant effects on CC values. The greatest CC (44.15) was observed in P64LE119 genotype and the lowest value (40.17 spad) was observed in PR63F73 genotype. In the second year of experiments, the greatest $\mathrm{CC}$ (36.11) in strong water-stress treatments was seen in $\mathrm{I}_{35} \mathrm{xP64LE119}$ interaction and the lowest value (34.04) was observed in $\mathrm{I}_{35} \mathrm{xPR} 63 \mathrm{~F} 73$ interaction. In no water-stress treatments of the second year, the greatest $\mathrm{CC}$ (49.32) was seen in $\mathrm{I}_{100} \times \mathrm{P} 64 \mathrm{LE} 119$ interaction and the lowest value (45.76) was observed in $\mathrm{I}_{100} \mathrm{xPR} 63 \mathrm{~F} 73$ interaction. Variance analyses revealed also for the second year that genotypes had significant effects on $\mathrm{CC}$ values with the greatest value (42.93) in P64LE119 genotype and the lowest value (39.70 spad) in PR63F73 genotype. The decrease in CC values was low in drought-resistant genotypes and high in sensitive genotypes (Table 3). Plants have different resistances to stress conditions and even different genotypes of the same plant may have different resistance levels (Win et al 2011) Robert et al (2016) reported decreased chlorophyll $\mathrm{a}, \mathrm{b}$ and total chlorophyll contents in sunflowers under water stress. Several other researchers also reported decreased leaf chlorophyll contents under water stress conditions (Demirtas \& Kirnak 2009; Zlatev et al 2010). It was also reported in previous studies that $\mathrm{CC}$ values might vary based on plant genotypes, cultivars, environmental and climate conditions (Testi et al 2008). Present findings comply with those earlier results.

In the first year of experiments, the greatest CWSI $(0.49)$ in strong water-stress treatments was seen in $\mathrm{I}_{35} \mathrm{xPR} 63 \mathrm{~F} 73$ interaction and the lowest $(0.31)$ was observed in $\mathrm{I}_{35} \mathrm{xP} 64 \mathrm{LE} 119$ interaction. In no waterstress treatments of the first year, the greatest CWSI (0.26) was seen in $\mathrm{I}_{100} \mathrm{xPR} 63 \mathrm{~F} 73$ interaction and the lowest (0.19) was observed in $\mathrm{I}_{100} \mathrm{xP64LE} 119$ interaction. Variance analyses revealed that genotypes also had significant effects on CWSI values with the greatest value (0.40) in PR63F73 genotype and the lowest value (0.26) in P64LE119 genotype. In the second of experiments, the greatest CWSI (0.56) in strong water-stress treatments was observed in $\mathrm{I}_{35} \mathrm{xPR} 63 \mathrm{~F} 73$ interaction and the lowest value $(0.37)$ was seen in $\mathrm{I}_{35} \mathrm{xP} 64 \mathrm{LE} 119$ interaction. In no water-stress treatments of the second year, the greatest CWSI (0.28) was observed in $\mathrm{I}_{100} \mathrm{xPR} 63 \mathrm{~F} 73$ interaction and the lowest value $(0.22)$ was seen in $\mathrm{I}_{100} \mathrm{xP64LE119}$ interaction. Variance analyses again revealed that genotypes had significant effects on CWSI values with the greatest value $(0.43)$ in PR63F73 genotype and the lowest value (0.29) in P64LE119 genotype. CWSI values of the second year were relatively higher than the CWSI values of the first year (Table 3). Drier conditions of the second year as compared to the first year increased evapotranspiration, thus CWSI values were found to be higher in the second year. Decreased CC and higher CWSI values were reported for water stress treatments (Moran et al 1994). Thusly, Khayatnezhad et al (2011) reported decreased chlorophyll contents and then reduced yields with water stress treatments in maize. Current findings comply with those earlier findings. P64LE119 with high yield, CC and low CWSI values were identified as resistant and the others were identified as sensitive. 
Table 3- Changes in yield and physiological properties of sunflower genotypes

\begin{tabular}{|c|c|c|c|c|c|c|}
\hline Treatments & $\begin{array}{l}\text { Yield } \\
\left(k g h a^{-1}\right)^{* *}\end{array}$ & $C W S I^{* *}$ & $\begin{array}{l}\text { Chlorophyll } \\
\text { content } \\
(\text { spad) }\end{array}$ & $\begin{array}{l}\text { Irrigation } \\
\text { water } \\
(\mathrm{mm})\end{array}$ & $\begin{array}{l}\text { ETa } \\
(\mathrm{mm})\end{array}$ & $\begin{array}{l}W U E \\
\left(k g d a^{-1}-m m\right)^{* *}\end{array}$ \\
\hline \multicolumn{7}{|c|}{2015 (First year) } \\
\hline \multicolumn{7}{|c|}{ Irrigation treatments } \\
\hline $\mathrm{I}_{100}(\mathrm{FI})$ & $4071.00 \mathrm{a}$ & $0.21 \mathrm{c}$ & $48.36 \mathrm{a}$ & 550.80 & 626.30 & $0.65 \mathrm{c}$ \\
\hline $\mathrm{I}_{70}^{100}(\mathrm{DI})$ & $3683.22 \mathrm{~b}$ & $0.38 \mathrm{~b}$ & $42.64 \mathrm{~b}$ & 402.81 & 478.34 & $0.77 \mathrm{~b}$ \\
\hline $\mathrm{I}_{35}^{70}(\mathrm{DI})$ & $2625.33 \mathrm{c}$ & $0.42 \mathrm{a}$ & $36.11 \mathrm{c}$ & 216.20 & 291.70 & $0.90 \mathrm{a}$ \\
\hline Average & 3459.85 & 0.34 & 42.37 & 389.94 & 465.44 & 0.77 \\
\hline $\operatorname{LSD}(0.05)$ & 1.79 & 0.008 & 1.25 & & & 0.050 \\
\hline \multicolumn{7}{|c|}{ Varieties } \\
\hline P64LE119 & $3519.00 \mathrm{a}$ & $0.26 \mathrm{c}$ & $44.15 \mathrm{a}$ & 364.37 & 439.87 & $0.80 \mathrm{a}$ \\
\hline P64LL62 & $3462.55 \mathrm{~b}$ & $0.36 \mathrm{~b}$ & $42.79 b$ & 374.18 & 449.68 & $0.77 \mathrm{~b}$ \\
\hline PR63F73 & $3398.00 \mathrm{c}$ & $0.40 \mathrm{a}$ & $40.17 \mathrm{c}$ & 383.68 & 459.18 & $0.74 \mathrm{c}$ \\
\hline Average & 3459.85 & 0.34 & 42.37 & 374.07 & 449.57 & 0.77 \\
\hline $\operatorname{LSD}(0.05)$ & 0.80 & 0.007 & 0.76 & & & 0,018 \\
\hline \multicolumn{7}{|c|}{ Varieties $\mathrm{x}$ irrigation treatments } \\
\hline $\mathrm{I}_{100} \mathrm{xP64LE119}$ & $4214.66 \mathrm{a}$ & $0.19 \mathrm{~h}$ & $50.33 \mathrm{a}$ & 526.69 & 602.09 & $0.70 \mathrm{~d}$ \\
\hline $\mathrm{I}_{100}^{100} \mathrm{xP64LL62}$ & $4083.64 \mathrm{~b}$ & $0.21 \mathrm{~g}$ & $48.51 \mathrm{~b}$ & 552.75 & 628.25 & $0.65 \mathrm{e}$ \\
\hline $\mathrm{I}_{100}^{100} \mathrm{xPR} 63 \mathrm{~F} 73$ & $3914.65 \mathrm{c}$ & $0.26 \mathrm{f}$ & $46.25 \mathrm{c}$ & 576.94 & 652.44 & $0.60 \mathrm{f}$ \\
\hline $\mathrm{I}_{70}^{100} \times 64 \mathrm{LE} 119$ & $3684.66 \mathrm{~d}$ & $0.28 \mathrm{e}$ & $44.99 \mathrm{c}$ & 390.91 & 466.41 & $0.79 \mathrm{c}$ \\
\hline $\mathrm{I}_{70}^{70} \mathrm{x}$ P64LL62 & $3683.33 \mathrm{~d}$ & $0.43 \mathrm{c}$ & $43.39 \mathrm{~d}$ & 409.15 & 484.65 & $0.76 \mathrm{c}$ \\
\hline $\mathrm{I}_{70}^{0} \mathrm{xPR} 63 \mathrm{~F} 73$ & $3681.63 \mathrm{e}$ & $0.45 \mathrm{~b}$ & $39.55 \mathrm{e}$ & 402.63 & 478.13 & $0.77 \mathrm{c}$ \\
\hline $\mathrm{I}_{35} \mathrm{x}$ P64LE119 & $2657.67 \mathrm{f}$ & $0.31 \mathrm{~d}$ & $37.13 \mathrm{f}$ & 207.23 & 282.73 & $0.94 \mathrm{a}$ \\
\hline$\stackrel{5}{\mathrm{I}}_{35 \mathrm{X}} \mathrm{P} 64 \mathrm{LL} 62$ & $2620.64 \mathrm{~g}$ & $0.46 \mathrm{~b}$ & $36.48 \mathrm{f}$ & 209.35 & 284.85 & $0.92 \mathrm{a}$ \\
\hline $\mathrm{I}_{35}^{35 \mathrm{x}} \mathrm{PR} 63 \mathrm{~F} 73$ & $2597.63 \mathrm{~h}$ & $0.49 \mathrm{a}$ & $34.73 \mathrm{~g}$ & 225.72 & 301.22 & $0.87 \mathrm{~b}$ \\
\hline${ }^{35}$ Average & 3459.85 & 0.34 & $42.37^{\circ}$ & 389.04 & 464.53 & 0.78 \\
\hline $\operatorname{LSD}(0.05)$ & 1.37 & 0.013 & 1.30 & & & 0.030 \\
\hline \multicolumn{7}{|c|}{2016 (Second year) } \\
\hline $\mathrm{I}_{100}(\mathrm{FI})$ & 3901.33 & $0.24 \mathrm{c}$ & $47.69 \mathrm{a}$ & 624.46 & 696.66 & $0.56 \mathrm{c}$ \\
\hline $\mathrm{I}_{70}(\mathrm{DI})$ & 3505.11 & $0.40 \mathrm{~b}$ & $41.57 \mathrm{~b}$ & 442.66 & 514.86 & $0.68 \mathrm{~b}$ \\
\hline $\mathrm{I}_{35}$ & 2538.33 & $0.47 \mathrm{a}$ & $34.86 \mathrm{c}$ & 245.09 & 317.29 & $0.80 \mathrm{a}$ \\
\hline Average & 3314.92 & 0.37 & 41.38 & 437.40 & 509.60 & 0.68 \\
\hline $\operatorname{LSD}(0.05)$ & ns & 0.017 & 1.72 & & & 0.005 \\
\hline \multicolumn{7}{|c|}{ Varieties } \\
\hline P64LE119 & $3393.33 \mathrm{a}$ & $0.29 \mathrm{c}$ & 42.93 & 399.09 & 471.29 & $0.72 \mathrm{a}$ \\
\hline P64LL62 & $3325.55 \mathrm{~b}$ & $0.39 \mathrm{~b}$ & 41.50 & 416.85 & 489.05 & $0.68 \mathrm{~b}$ \\
\hline PR63F73 & $3225.88 \mathrm{c}$ & $0.43 \mathrm{a}$ & 39.70 & 431.84 & 504.04 & $0.64 \mathrm{c}$ \\
\hline Average & 3314.92 & 0.37 & 41.38 & 415.92 & 488.12 & 0.68 \\
\hline $\operatorname{LSD}(0.05)$ & 48.5 & 0.012 & ns & & & 0.170 \\
\hline \multicolumn{7}{|c|}{ Varieties $\mathrm{x}$ irrigation treatments } \\
\hline $\mathrm{I}_{100} \mathrm{xP64LE119}$ & $3974.66 \mathrm{a}$ & $0.22 \mathrm{~h}$ & $49.32 \mathrm{a}$ & 601.47 & 673.67 & $0.59 \mathrm{e}$ \\
\hline $\mathrm{I}_{100}^{100} \mathrm{xP64LL62}$ & $3929.33 \mathrm{a}$ & $0.24 \mathrm{~g}$ & $47.99 \mathrm{~b}$ & 629.46 & 701.66 & $0.56 \mathrm{ef}$ \\
\hline $\mathrm{I}_{100}^{100} \mathrm{xPR63F73}$ & $3800.00 \mathrm{~b}$ & $0.28 \mathrm{f}$ & $45.76 \mathrm{c}$ & 644.78 & 716.98 & $0.53 \mathrm{f}$ \\
\hline $\mathrm{I}_{70} \mathrm{x}$ P64LE119 & $3519.67 \mathrm{c}$ & $0.30 \mathrm{e}$ & $43.36 \mathrm{~d}$ & 430.61 & 502.81 & $0.70 \mathrm{~cd}$ \\
\hline $\mathrm{I}_{70}^{10} \times$ P64LL62 & $3499.66 \mathrm{c}$ & $0.44 \mathrm{c}$ & $42.05 \mathrm{e}$ & 442.46 & 514.66 & $0.68 \mathrm{~d}$ \\
\hline $\mathrm{I}_{70}^{0} \mathrm{xPR} 63 \mathrm{~F} 73$ & $3496.00 \mathrm{c}$ & $0.46 \mathrm{~b}$ & $39.30 \mathrm{f}$ & 449.59 & 521.79 & $0.67 \mathrm{~d}$ \\
\hline $\mathrm{I}_{35} \mathrm{x}$ P64LE119 & $2685.66 \mathrm{~d}$ & $0.37 \mathrm{~d}$ & $36.11 \mathrm{~g}$ & 232.98 & 305.18 & $0.88 \mathrm{a}$ \\
\hline$\stackrel{5}{\mathrm{I}}_{35 \mathrm{X}} \mathrm{P} 64 \mathrm{LL} 62$ & $2551.33 \mathrm{e}$ & $0.48 \mathrm{~b}$ & $34.45 \mathrm{~h}$ & 238.94 & 311.14 & $0.82 \mathrm{~b}$ \\
\hline $\mathrm{I}_{35}^{30 \mathrm{xPR} 63 \mathrm{~F} 73}$ & $2378.00 \mathrm{f}$ & $0.56 \mathrm{a}$ & $34.04 \mathrm{~h}$ & 253.55 & 325.75 & $0.73 \mathrm{c}$ \\
\hline${ }^{35}$ Average & 3314.92 & 0.37 & 41.38 & 435.98 & 508.18 & 0.68 \\
\hline $\operatorname{LSD}(0.05)$ & 84.00 & 0.020 & 1.02 & & & 0.041 \\
\hline
\end{tabular}


Significant correlations were observed between yield and CWSI and between yield and $\mathrm{CC}$ values $(\mathrm{P}<0.01)$. The correlation coefficients $(\mathrm{r})$ for the relationships of yield with $\mathrm{CC}$, CWSI and WUE are presented in Table $4 \mathrm{a}$ and $\mathrm{b}$ respectively for the years 2015 and 2016. Each year was assessed in itself to see the year-based variations in correlation and regression between the investigated traits. Significant correlations were observed between the investigated traits in $2015(\mathrm{P}<0.01)$. There was an increasing correlation between $\mathrm{CC}$ and yield $\left(\mathrm{r}=0.925^{* *}\right)$. The regression analysis between these two parameters revealed a linear relationship as of Yield $=-1253.00+111.00 \times(C C)$. In this relation, 1 spad increase in CC corresponds to $1.142 \mathrm{~kg}$ increase in yield. Coefficient of determination was observed as $\mathrm{R}^{2}=86 \%$. In other words, the change in yield was $86 \%$ influenced by CC. There was decreasing correlation between CWSI and yield $\left(r=-0.664^{* *}\right)$. The regression analysis between these two parameters revealed a negative linear relationship as of Yield $=4809.31-3887.77 \mathrm{x}$ CWSI. In this relationship, 1 unit increase in CWSI corresponds to $0.921 \mathrm{~kg}$ decrease in yield. Coefficient of determination was identified as $\mathrm{R}^{2}=$ $44.6 \%$.

Table 4- The correlation coefficients between yield and other parameters

\begin{tabular}{lcccc}
\hline$a(2015)$ & Yield & WUE & CWSI & $C C$ \\
\hline Yield & & $-0.782^{* *}$ & $-0.664^{* *}$ & $0.925^{* *}$ \\
WUE & $-0.782^{* *}$ & & $0.594^{* *}$ & $-0.794^{* *}$ \\
CWSI & $-0.664^{* *}$ & $0.594^{* *}$ & & $-0.837^{* *}$ \\
CC & $0.925^{* *}$ & $-0.794^{* *}$ & $-0.837^{* *}$ & \\
\hline$b(2016)$ & Yield & WUE & CWSI & $C C$ \\
\hline Yield & & $-0.825^{* *}$ & $-0.797^{* *}$ & $0.953^{* *}$ \\
WUE & $-0.825^{* *}$ & & $0.577^{* *}$ & $-0.821^{* *}$ \\
CWSI & $-0.797^{* *}$ & $0.577^{* *}$ & & $-0.879^{* *}$ \\
CC & $0.953^{* *}$ & $-0.821^{* *}$ & $-0.879^{* *}$ & \\
\hline
\end{tabular}

**, $\mathrm{P}<0.01$; WUE, water use efficiency; CWSI, crop water stress index; CC, chlorophyll content

Significant correlations were also observed between all parameters in $2016(\mathrm{P}<0.01)$. There was a highly positive correlation between $\mathrm{CC}$ and yield $\left(\mathrm{r}=0.953^{* *}\right)$. The regression analysis between these two parameters revealed a linear relationship as of Yield $=-926.12+102.65 \times$ CC. In this relationship, 1 spad increase in $\mathrm{CC}$ corresponds to $0.823 \mathrm{~kg}$ increase in yield. Coefficient of determination was identified as $\mathrm{R}^{2}=90 \%$. In other words, the change in yield was $90 \%$ influenced by CC. There was a decreasing correlation between CWSI and yield $\left(\mathrm{r}=-0.797^{* *}\right)$. The regression analysis between these two parameters revealed a linear relationship as of Yield $=4840.49-4071.49 \times$ CWSI. In this relationship, 1 unit increase in CWSI corresponds to $0.769 \mathrm{~kg}$ decrease in yield. Coefficient of determination was identified as $\mathrm{R}^{2}=63.9 \%$. In other words, the change in yield was $63.9 \%$ influenced by CWSI.

\section{Conclusions}

As the average of two years, the greatest yield was obtained from $\mathrm{I}_{100} \times$ P64LE119 interaction $\left(4094.66 \mathrm{~kg} \mathrm{ha}^{-1}\right)$ and the lowest yield was obtained from $\mathrm{I}_{35} \times$ PR63F73 interaction $\left(2487.81 \mathrm{~kg} \mathrm{ha}^{-1}\right)$. The greatest CC was observed in $\mathrm{I}_{100} \mathrm{xP} 64 \mathrm{LE} 119$ interaction (49.83 spad) and the lowest value was seen in $\mathrm{I}_{35} \mathrm{xPR} 63 \mathrm{~F} 73$ interaction (34.39 spad). The greatest CWSI was observed in $\mathrm{I}_{35} \mathrm{xPR} 63 \mathrm{~F} 73$ interaction (0.53) and the lowest CWSI was observed in $\mathrm{I}_{100} \mathrm{xP} 64 \mathrm{LE} 119$ interaction (0.21). There was an inverse relationship between irrigation water and CWSI and a direct relationship between irrigation water and CC. CWSI values decreased and $\mathrm{CC}$ values increased with increasing irrigation water quantities. However, such increase or decreases were not constant and varied based on genotypes even in no water-stress treatments. The greatest WUE $\left(0.76 \mathrm{~kg}^{\mathrm{da}} \mathrm{mm}^{-1}\right)$ was observed in P64LE119 genotype and it was placed in group A. The lowest WUE $\left(0.71 \mathrm{~kg} \mathrm{da} \mathrm{mm}^{-1}\right)$ was observed in PR63F73 genotype and it was placed in group C. Therefore, the genotype P64LE119 was found to be prominent both in strong water-stress and no waterstress treatments and optimally converted applied irrigation water into the yield. The water stressinduced reduction in CC was low in water stressresistant genotypes and high in sensitive genotypes. 
In brief, in strong water-stress and no water-stress treatments of the experimental years, yield, CWSI and CC values of P64LE119 genotype were above the averages. Therefore, P64LE119 genotype was identified as water stress-resistant and can be used in further studies to be carried out for resistance to abiotic stress factors.

\section{Acknowledgements}

The authors thank to Siirt University Scientific Research Projects Department for their financial support and to Journal of Agricultural Sciences for their technical supports. The authors are also grateful to Assoc. Prof. Dr. Zeki GOKALP (a Certified English Translator and an expert in Biosystems Engineering) for his critical reading and through syntactic corrections of the manuscript.

\section{References}

Afkari A (2010). The effect of water deficit on characteristics physiological-chemical of sunflower (Helianthus annuus L.) varieties. Advances in Environmental Biology 4(1): 24-30

Alahdadi I, Oraki H \& Khajani F P (2011). Effect of water stress on yield and yield components of sunflower genotypes. African Journal of Biotechnology 10(34): 6504-6509

Alderfasi A A \& Nielsen D C (2001). Use of crop water stress index for monitoring water status and scheduling irrigation in wheat. Agriculture Water Management 47: 69-75

Ali M D \& Shui L T (2009). Potential evapotranspiration model for Muda Irrigation Project, Malaysia. Water Resources Management 23(1): 57-69

Blake G R \& Hartge K H (1986). Bulk density. In: Klute, A. (ed.), Methods of Soil Analysis, Physical and Mineralogical Methods, Part 1. American Society of Agronomy, Madison, Wisconsin, USA, Monograph 9, pp. 363-375

Chaves M M (1991). Effect of water deficits on carbon assimilation. Journal of Experimental Botany 42(1): $1-16$

Chimenti C, Pearson A \& Hall J (2002). Osmotic adjustment and yield maintenance under drought in sunflower. Field Crops Research 75(2): 235-246
Choudhury B J \& Idso S B (1984). Simulating sunflower canopy temperatures to infer root-zone soil water potential. Agricultural and Forest Meteorology 31: 69-78

Cornic G (2000). Drought stress inhibits photosynthesis by decreasing stomatal aperture-not by affecting ATP synthesis. Trends in Plant Science 5(5): 187-188

Darvishzadeh R, Azizi M, Hatami-Maleki H, Bernousi I, Abdollahi Mandoulakani B, Jafari M \& Sarrafi A (2010). Molecular characterization and similarity relationships among sunflower (Helianthus annuus L.) inbred lines using some mapped simple sequence repeats. African Journal of Biotechnology 9(43): 7280-7288

Demirtas M \& Kirnak H (2009). Farklı sulama yöntemleri ve aralıklarının fizyolojik parametrelere etkisi. Yüzüncü Yıl Üniversitesi Tarım Bilimleri Dergisi 19: 79-83

Der G \& Everitt B S (2002). A Handbook of Statistical Analyses Using SAS. Second Edition. CRC Press LLC, 2000 N.W. Corporate Blvd., Boca Raton, Florida 3431. USA

Flexas J \& Medrano H (2002). Drought-inhibition of photosynthesis in C3 plants: Stomatal non-stomatal limitations revisited. Annals of Botany 89(2): 183-189

Gencoglan C \& Yazar A (1999). Çukurova koşullarında yetiştirilen I. ürün mısır bitkisinde infrared termometre değerlerinden yararlanılarak bitki su stresi indeksi (CWSI) ve sulama zamanının belirlenmesi. Turkish Journal of Agriculture and Forestry 23: 87-95

Gunes A, Inal A, Adak M S, Bagci E G, Cicek N \& Eraslan F (2008). Effect of drought stress implemented at pre-and post-anthesis stage on some physiological parameters as screening criteria in chickpea cultivars. Russian Journal of Plant Physiology. 55(1): 59-67

Gungor Y, Erozel A Z \& Yildirim O (2006). Sulama. Ankara Üniversitesi Ziraat Fakültesi Yayınları: 1592, Ders Kitab1: 424, Ankara

Hajhassani-Asl N, Roshdi M, Ghafari M, Alizadeh A \& Moradi-Aghdam A (2009). The effect of drought stress and defoliation on some agronomic traits, seed yield and yield components of sunflower (Alestar hjbrid). Danesh Novin Journal 5(15): 27-39

Idso S B (1982). Non-Water-Stressed Baselines: A Key to Measuring and Interpreting Plant Water Stress. Agriculture Meteorol 27(1-2): 59-70

Idso S B, Jackson R D, Pinter P J, Regina to R J \& Hatfield J L (1981). Normalizing The Stress-Degree- 
Day Parameter For Environmental Variability. Agricultural Meteorology 24: 45-55

Jackson R D \& Reginato R J (1981). Canopy temperature as a crop water stress indicator. Water Resources Research 17: 1133-1138

Kaleem S, Hassan F U \& Saleem A (2009). Influence of environmental variations on physiological attributes of sunflower. African Journal Biotechnol 8(15): 35313539

Kassab O M, Abo Ellil A A \& Abo El-Kheir MS (2012). Water use efficiency and productivity of two sunflower cultivars as influenced by three rates of drip irrigation water. Journal of Applied Sciences Research 8(7): 3524-3529

Khayatnezhad M, Gholamin R, Jamaati-e-Somarin S H \& Zabihie Mahmoodabad R (2011). The leaf chlorophyll content and stress resistance relationship considering in Corn cultivars (Zea mays). Advances in Environmental Biology 5(1): 118-122

Klute A (1986). Water retention: In: Klute, A. (Ed.), Methods of Soil Analysis. Part 2, Physical and Mineralogical Methods, $2^{\text {nd }}$ Edition, Agronomy Monograph No: 9, Soil Science Society of America, Madison, WI. pp. 635-653

Kozlowski T T \& Pallardy S G (1997). Physiology of Woody Plants, Academic Press, 642 pp, San Diego

Moran M S, Clarke T R, Inoue Y \& Vidal A (1994). Estimating crop water deficit using the relation between surface-air temperature and spectral vegetation index. Remote Sensing of Environment 49(3): 246-263

Moroni I F, Fraysse M, Presotto A \& Cantamutto M (2012). Evaluation of Argentine wild sunflower biotypes for drought stress during reproductive stage. $18^{\text {th }}$ International Sunflower Conference, 27 February-1 March, Argentina, pp. 420-425

Mozaffari K, Arshi Y \& Zeinali-Khanghah H (1996). Research on the effects of water stress on some morphophysiological traits and yield components of sunflower (Helianthus annuus L.). Seed and Plant Journal 12(3): 24-33

Oraki H, Khajani F P \& Aghaalikhana M (2012). Effect of water deficit stress on proline contents, solublesugars, chlorophyll and grain yield of sunflower hybrids. African Journal of Biotechnology 11(1): 164-168

Reginato R J (1983). Field qualification of crop water stress. The American Society of Agricultural Engineers 26(3): 772-781

Reginato R J \& Howe J (1985). Irrigation scheduling using crop indicators. Journal of Irrigation and Drainage Engineering Asce 111(2): 125-133

Robert GA, Rajasekar M\& Manivannan P(2016). Triazoleinduced drought stress amelioration on growth, yield, and pigments composition of Helianthus annuus L. (sunflower). International Multidisciplinary Research Journal 5: 6-15

Sahin U, Kiziloglu F M, Anapali O \& Okuroglu M (2007). Determining crop and pan coefficients for sugar beet and potato crops under cool season semiarid climatic conditions. Journal of Agronomy Crop Science 193(2): 146-152

Scott H D (2000). Soil-plant-water relations. Soil physics. Agricultural and environmental applications. Iowa State University, 2121 South State Avenue, Ames, Iowa, pp. 322-355

Skoric D (2009). Sunflower breeding for resistance to abiotic stresses. Helia 32(50): 1-16

Testi L, Goldhamer D \& Iniesta F (2008). Crop water stress index is a sensitive water stress indicator in pistachio trees. Irrigation Science 26: 395-405

Tuzuner A (1990). Toprak ve Su Analiz Laboratuvarları El Kitabı, T.C. Tarim Orman ve Köyişleri Bakanlığı Köy Hizmetleri Genel Müdürlüğü, Ankara, Türkiye

Walker G K \& Hatfield J L (1979). Test of stress-degreeday concept using multiple planting dates of red kidney beans. Agronomy Journal 71: 967-971

Zaeifizade M \& Goliov R (2009). The effect of the interaction between genotypes and drought stress on the superoxide dismutase and chlorophyll content in durum wheat landraces. Turkish Journal of Biology 33(1): 1-7

Zlatev Z, Vassilev A, Goltsev V \& Popov G (2010). Drought-induced changes in chlorophyll fluorescence of young bean plants. Agriculture Science 2(2): 75-79 